\title{
Making the case for edible microorganisms as an integral part of a more sustainable and resilient food production system
}

\author{
Tomas Linder ${ }^{1}$
}

Received: 13 November 2018 / Accepted: 6 March 2019 / Published online: 22 March 2019

(C) The Author(s) 2019

\begin{abstract}
Edible microbial biomass derived from bacteria, yeasts, filamentous fungi or microalgae is a promising alternative to conventional sources of food and feed. Microorganisms are a good source of protein, vitamins and, in some cases, also contain beneficial lipids. The ability of microorganisms to use simple organic substrates for growth permits industrial-scale cultivation of edible microbial biomass in geographical locations that would not compete with agricultural production. Only a handful of microbial products are currently available for human consumption. The use of microbial biomass for animal feed is limited by access to low-cost growth substrates and competition from conventional feed sources such as soy and fishmeal. At a time when the global food production system is threatened by the effects of climate change, the production of edible microorganisms has the potential to circumvent many of the current environmental boundaries of food production as well as reducing its environmental impact. Photosynthetic microorganisms such as cyanobacteria and microalgae can be cultivated for food and feed independently of arable land. In addition, recent technological developments in atmospheric carbon dioxide $\left(\mathrm{CO}_{2}\right)$ capture, extraction and catalytic conversion into simple organic compounds can be used for cultivation of edible microbial biomass for food and feed in a manner that is wholly independent of photosynthesis. The future possibilities, challenges and risks of scaled-up production of edible microbial biomass in relation to the global food system and the environment are discussed.
\end{abstract}

Keywords Carbon capture $\cdot$ Microorganism $\cdot$ Single cell protein $\cdot$ Sustainable intensification

\section{The current challenge}

Population growth, changing consumption patterns and a warming climate are collectively putting unprecedented strain on the global food production system. The human population is estimated to reach 9.6-12.3 billion people by the year 2100 (Gerland et al. 2014). Contemporary agriculture already exerts a significant environmental footprint in terms of greenhouse gas (GHG) emissions (Vermeulen et al. 2012), freshwater use (Hoekstra and Mekonnen 2012), eutrophication (Diaz and Rosenberg 2008), land degradation (Montgomery 2007) and loss of biodiversity (Newbold et al. 2015). The predicted expansion of the global food production system during the next couple of decades is expected to nearly double environmental

Tomas Linder

tomas.linder@slu.se

1 Department of Molecular Sciences, Swedish University of Agricultural Sciences, Box 7015, SE-750 07 Uppsala, Sweden pressures by 2050 when compared to 2010 levels (Springmann et al. 2018). Rising temperatures resulting from anthropogenic climate change are, in turn, expected to reduce agricultural yields of major crops (Zhao et al. 2017), which include increased yield losses to crop pests (Deutsch et al. 2018) and extreme weather events (Lesk et al. 2016). Decreased agricultural yields would necessitate further agricultural expansion in order to keep up with demand. Such expansion would in turn be expected to exacerbate agricultural emissions that then risk lowering yields further through climate change. Retaining the current food production model to satisfy future global food demand therefore has the potential to trap humanity in a vicious spiral of gradually decreasing agricultural output (Harvey and Pilgrim 2011).

A number of countermeasures have been proposed to increase food production output and simultaneously reduce its inherent environmental costs. Such actions include increasing agricultural yields per unit surface area, more efficient management of agricultural inputs (water and fertilizer use), changes in dietary patterns and reducing food waste (Horton 2017; McKenzie and Williams 2015; Springmann et al. 2018). 
There is still some operating space for closing yield gaps across the globe (Foley et al. 2011; Onyutha 2018) but global trends in agricultural yields for the major crops suggest that yield increases alone will be insufficient for adequately feeding the human population mid-century (Grassini et al. 2013; Ray et al. 2013), assuming that current dietary trends prevail. The majority of land area currently dedicated to food production is used for feeding animals - either as pasture or for the cultivation of feed crops (Foley et al. 2011). Hence, a dietary transition towards predominantly plant-based foods could significantly alleviate pressure on the environment (Cassidy et al. 2013). However, the current global trend is the opposite with improving living standards causing an increase in per capita consumption of animal protein such as meat, eggs and dairy products (Gerbens-Leenes et al. 2010). Any policy efforts aiming to reverse this dietary transition are further hampered by entrenched attitudes to meat consumption that exist in different cultures (Happer and Wellesley 2019).

At this critical juncture in human history, alternatives to conventional means of food production urgently need to be considered. Some of the alternative strategies for food production that regularly feature in public discourse include farming insects for human consumption (van Huis 2013), cultivation of artificial "lab-grown" meat (Jones 2010) and vertical farming of crops (Despommier 2009). Although the concept of using microorganisms as both food and feed is at least several centuries old, it has received significantly less attention in the current public debate. The present review will introduce some of the unique properties of microorganisms that make them a promising alternative to conventional sources of food and feed. The future challenges and possibilities as well as potential risks of large-scale production of edible microbial biomass will be discussed. Particular emphasis will be given to the potential of pairing cultivation of edible microorganisms with emerging technologies within the field of carbon dioxide $\left(\mathrm{CO}_{2}\right)$ capture and extraction from ambient air and its subsequent conversion into simple organic compounds. For the benefit of non-specialist readers, relevant technical terms have been highlighted in italics when they are first mentioned. Scientific names of individual microbial species are also italicized according to standard convention.

\section{A primer on microorganisms}

Microorganisms typically adopt two lifestyles, existing either as individual cells or as thin filaments of cells that are attached end-to-end. Some microorganisms may switch between these two lifestyles depending on environmental conditions or the stage of their lifecycle. If external conditions are favorable and nutrients are abundant, some microorganisms are capable of very rapid growth with cell division occurring approximately every $20 \mathrm{~min}$ in the case of the intestinal bacterium
Escherichia coli to every 90 min for the common baker's yeast Saccharomyces cerevisiae.

All currently known microorganisms belong to one of the three kingdoms of life: the eukaryotes, the bacteria or the archaea (Hug et al. 2016). The eukaryotes (which also include multicellular organisms such as animals, land plants, fruit body-forming fungi and macroalgae) are distinguished by membrane-bound structures (so-called organelles) within their cells such as the cell nucleus, mitochondria and chloroplasts. Eukaryotic microorganisms include microscopic fungi (single-celled yeasts as well as filamentous fungi), microalgae, ciliates and amoebae. All currently known members of the remaining two kingdoms of bacteria and archaea are exclusively microorganisms. Although bacteria are often associated with disease, these organisms play an absolutely vital role in maintaining planetary geochemical cycles as well as directly benefiting plants and animals through countless examples of symbiotic relationships. The bacterial kingdom includes photosynthetic species, which are commonly referred to as "bluegreen algae" but the term cyanobacteria will be used throughout this review. (Even though cyanobacteria are technically a form of microalgae, the term "microalgae" will be used exclusively in this review to denote single-celled or filamentous eukaryotic algae.) Archaea are superficially similar to bacteria but differ significantly in the biochemical composition of their cellular structures. The archaea are often found in extreme environments such as hot springs but also in more conventional environments such as oxygen-poor aquatic sediments (Jarrell et al. 2011). Archaea play an important role in many global geochemical cycles and a sub-set of archaea are uniquely responsible for the biological production of methane gas $\left(\mathrm{CH}_{4}\right)$, which will be of significance later in this review.

Microorganisms are notably adept at using simple organic (carbon-containing) compounds in their immediate environment to grow and divide. The extent of this ability gives rise to a functional classification scheme that will be briefly introduced here (Fig. 1a) and which will be useful to the nonspecialist reader in order to follow the remainder of this review. Microorganisms are divided into two main functional categories: autotrophic microorganisms and heterotrophic microorganisms. Autotrophic microorganisms can assimilate $\mathrm{CO}_{2}$ directly as a source of carbon (C) to grow and divide (Berg 2011) while heterotrophic microorganisms can only assimilate organic $\mathrm{C}$ that has already been synthesized ("fixed") from $\mathrm{CO}_{2}$. Autotrophic microorganisms are classified further according to the energy source used to assimilate $\mathrm{CO}_{2}$. Photoautotrophic microorganisms harvest light energy to assimilate $\mathrm{CO}_{2}$ through the process of photosynthesis while chemoautotrophic microorganism make use of chemical energy to assimilate $\mathrm{CO}_{2}$ through the process of chemosynthesis. The range of compounds that can be used as energy sources by chemoautotrophic microorganisms include hydrogen sulfide gas $\left(\mathrm{H}_{2} \mathrm{~S}\right)$, elemental sulfur, ferrous iron $\left(\mathrm{Fe}^{2+}\right)$ and 
a

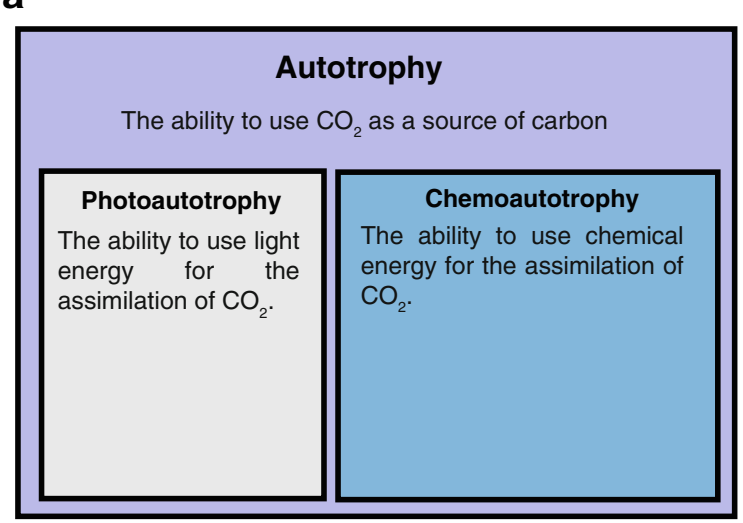

b<smiles>CO</smiles>

$\mathrm{H}$

methane

$\left(\mathrm{CH}_{4}\right)$ methanol $\left(\mathrm{CH}_{3} \mathrm{OH}\right)$
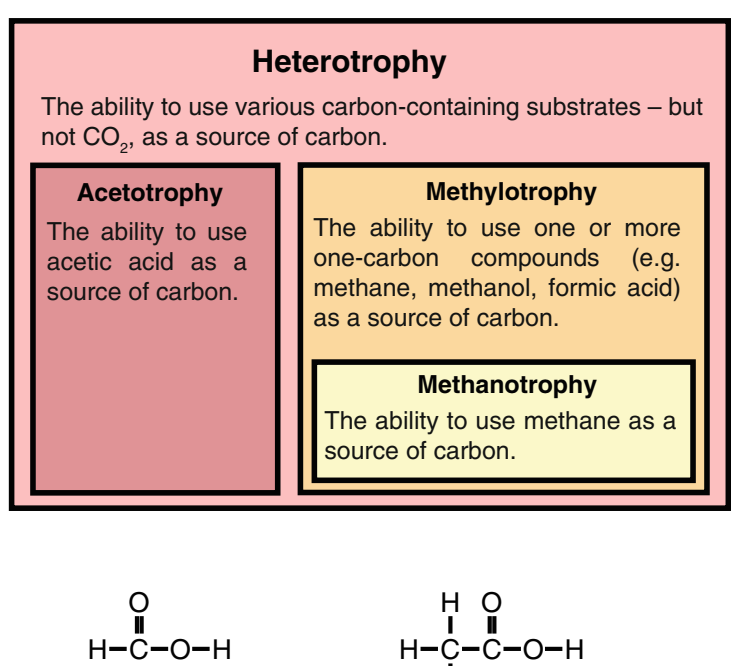

formic acid $(\mathrm{HCOOH})$<smiles>CC(O)O</smiles>

acetic acid $\left(\mathrm{CH}_{3} \mathrm{COOH}\right)$

Fig. 1 Carbon assimilation by microorganisms. a Trophic classification of microorganisms. b Structural formulae of simple organic compounds commonly assimilated by microorganisms

ammonia $\left(\mathrm{NH}_{3}\right)$. Hydrogen-oxidizing chemoautotrophic microorganisms constitute a subset of chemoautotrophic microorganisms, which use the chemical energy embedded in hydrogen gas $\left(\mathrm{H}_{2}\right)$ to assimilate $\mathrm{CO}_{2}$. This particular category of microorganisms will feature later in this review.

Heterotrophic microorganisms can also be further classified according to the type of fixed $\mathrm{C}$ they can assimilate. The three forms of heterotrophy that will be relevant to this review are acetotrophy, methylotrophy and methanotrophy. Acetotrophic microorganisms have the ability to assimilate acetic acid (Fig. 1b) into biomass, which is a very common ability among microorganisms. Methylotrophic microorganisms have the ability to assimilate one or more one-C compounds such as methane, methanol or formic acid into biomass (Fig. 1b). Methanotrophy is a form of methylotrophy that specifically refers to the ability to assimilate methane into biomass. It should be noted that different trophic categories are not necessarily mutually exclusive. Many microorganisms are capable of both autotrophy and heterotrophy. Likewise different categories of heterotrophy are not mutually exclusive. For example, many microorganisms are capable of both acetotrophy and methylotrophy.

\section{Past and current use of microorganisms as food and feed}

The concept of using microorganisms as a source of food and feed is at least several centuries old. In the sixteenth century, the native population of today's Mexico City was known to harvest mats of cyanobacteria belonging to the genus Arthrospira (commonly known today as Spirulina) from the alkaline waters of nearby Lake Texcoco (Ciferri 1983). There are also contemporary instances of the use of Spirulina for human consumption, such as Lake Chad in Africa where Spirulina biomass (known locally as Dihé) is harvested and dried into biscuits (Abdulqader et al. 2000). During the First World War, Germany maintained large-scale production of yeast biomass to replace previously imported sources of protein feed (Ugalde and Castrillo 2002). The industry term single-cell protein (SCP) was coined in the late 1960s and refers to protein derived from microorganisms. However, the term SCP is also often used to describe edible microbial biomass as a whole even though this may include non-protein components such as lipids and carbohydrates. Some microorganisms are used predominantly for the production of lipids that can be used for either food, feed or fuel applications. Such microbial lipids are commonly referred to as single-cell oil (SCO). To avoid confusion, the term "microbial biomass" will be used consistently throughout this review to refer to any edible product derived from microorganisms, irrespective of whether it refers to the total biomass or a particular fraction such as proteins or lipids.

The nucleic acid content of crude microbial biomass is too high for direct consumption by humans as well as many animals and can cause gout-like symptoms as a result of elevated levels of uric acid in the blood following ingestion (Edozien et al. 1970). Crude microbial biomass must therefore be pretreated to remove nucleic acids, usually through heat treatment. In addition, the cell walls of many kinds of microorganisms destined 
for either human or animal consumption are often ruptured through processes such as grinding in order to increase digestibility (Ritala et al. 2017). As a consequence of these treatments, processed microbial biomass predominantly consists of dead cells. This distinguishes edible microbial biomass from probiotics, where the latter consists of live microorganisms that mediate health benefits through interactions with the host gut as well as the resident gut microbiota (Syngai et al. 2016).

Selected examples of food and feed products derived from microbial biomass are listed in Table 1. At present there are only a few microbial food products sold for human consumption globally. Sandwich spreads derived from extracts of spent brewer's yeast (e.g. Marmite) have been consumed since the early twentieth century (Unilever 2019). The meat substitute Quorn ${ }^{\mathrm{TM}}$, which is derived from the filamentous fungus Fusarium venenatum, has been commercially available in the United Kingdom since 1985 and is now sold in many countries world-wide (Finnigan et al. 2017). Spirulina is marketed as a nutritional supplement rather than a food product because of concerns regarding the introduction of biotic and abiotic contaminants during its production (Heussner et al. 2012).

There is currently renewed interest into the development and commercialization of microbial sources of animal feed (Ritala et al. 2017) following a previous market decline during the late 1980s/early 1990s (Ugalde and Castrillo 2002). At present, cost-competiveness with conventional feed sources (such as soy or fishmeal) is the main factor that determines the commercial potential of microbial sources of feed. Controlled cultivation of food- or feed-grade microorganisms in most cases require capital-intensive facilities that include large fermentation tanks $\left(10-1000 \mathrm{~m}^{3}\right)$, advanced instrumentation for maintaining optimal growth conditions (e.g. temperature, $\mathrm{pH}$, mixing, air flow, supply of nutrients) as well as equipment for harvesting the microbial biomass from the surrounding liquid growth substrate.

Production costs for microbial biomass are also greatly influenced by the choice of organic substrate for microbial growth - typically referred to as feedstock (Cooney et al. 1980;
Hamdan and Senez 1992). Microorganisms can be cultivated on a variety of simple organic feedstocks such as sugars, alcohols, organic acids and hydrocarbons. Manufacturers of microbial biomass often favor low-cost organic byproducts from the food production industry such as molasses, vegetable starch and whey (Hamdan and Senez 1992). There is also an ongoing effort to achieve efficient extraction of usable sugars from otherwise inedible byproducts of the agriculture and forestry sectors (e.g. straw, sawdust, woodchips) with the help of enzymes from wood-degrading bacteria and fungi. In addition, recalcitrant plant biomass such as wood can be converted into methanol through thermochemical gasification (Singh et al. 2017). The methanol can then be used for the cultivation of methylotrophic bacteria and fungi. Methane, the main constituent of natural gas and biogas, is currently used for the production microbial feed using methanotrophic bacteria (Øverland et al. 2010; Table 1). So-called biomethane is a renewable feedstock that can be produced through natural microbial degradation of food waste, manure or sewage sludge under oxygen-free (anaerobic) conditions (Khalid et al. 2011). Fossil methane is also an abundant and currently low-cost feedstock but cannot be considered renewable since its constituent $\mathrm{C}$ will eventually end up as $\mathrm{CO}_{2}$ in the atmosphere through cellular respiration.

\section{Nutritional value, functional properties and safety aspects of edible microbial biomass}

Table 2 lists basic nutritional properties for three microbial food products intended for human consumption compared to selected basic foodstuffs. The protein content of microbial biomass is generally high (30-60\% of dry weight) and can reach $70 \%$ of the total dry weight (Matassa et al. 2016; Ritala et al. 2017). Protein quality, as measured by essential amino acid content and digestibility, will depend on the amino acid profile of the individual microorganism vis-à-vis the amino acid requirements of the target animal (Boisen et al. 2000).

Table 1 Examples of food and feed products based on microbial biomass

\begin{tabular}{|c|c|c|c|c|}
\hline Product name & Species & Type & Feedstock & Company \\
\hline All-G Rich & Aurantiochytrium limacinum & Non-photosynthetic microalga & (Not disclosed) & Alltech \\
\hline FeedKind & Methylococcus capsulatus & Bacterium & Methane & Calysta Inc. \\
\hline KnipBio Meal & Methylobacterium extorquens & Bacterium & Methanol & KnipBio \\
\hline Provesta $^{\#}$ & Pichia pastoris & Yeast & Methanol & Phillips Petroleum Co. \\
\hline Pruteen $^{\#}$ & Methylophilus methylotrophus & Bacterium & Methanol & Imperial Chemical Industries (ICI) \\
\hline Quorn ${ }^{\mathrm{TM}}$ & Fusarium venenatum & Filamentous fungus & Glucose & Marlow Foods Ltd. \\
\hline Spirulina & Arthrospira sp. & Cyanobacterium & $\mathrm{CO}_{2}$ & various \\
\hline UniProtein & Methylococcus capsulatus & Bacterium & Methane & Unibio $\mathrm{A} / \mathrm{S}$ \\
\hline
\end{tabular}

${ }^{\#}$ Discontinued 
Table 2 Basic nutritional properties of microbial food products compared to a selection of basic foodstuffs

\begin{tabular}{lllll}
\hline Product & Energy (kcal/g) & Protein $(\%)$ & Lipids (\%) & Carbohydrates (\%) \\
\hline Mycoprotein ingredient & 3.4 & 45.0 & 13.0 & 35.0 \\
Spirulina & 2.8 & 63.5 & 4.2 & 25.9 \\
Yeast extract & 3.1 & 40.4 & 1.5 & 34.6 \\
Atlantic salmon (farmed, raw) & 5.9 & 58.2 & 38.2 & 0.0 \\
Chicken egg (whole, raw) & 6.0 & 52.7 & 39.9 & 3.0 \\
Chicken breast (skinless, raw) & 4.6 & 86.2 & 10.0 & 0.0 \\
Clam (raw) & 3.5 & 69.8 & 4.6 & 17.0 \\
Cow's milk (3.7\% fat) & 5.2 & 26.6 & 29.7 & 37.8 \\
Ground beef (grass-fed, raw) & 6.0 & 59.1 & 38.7 & 0.0 \\
Ground pork (raw) & 6.8 & 43.3 & 54.4 & 0.0 \\
Kelp (raw) & 2.3 & 9.1 & 3.0 & 52.0 \\
Lentils (raw) & 3.8 & 26.8 & 1.2 & 69.1 \\
Maize flour (yellow, whole-grain) & 4.1 & 7.8 & 4.3 & 86.3 \\
Potato (raw) & 3.5 & 15.4 & 0.6 & 74.4 \\
Rice (white, long-grain, raw) & 4.1 & 8.1 & 0.7 & 90.5 \\
Shrimp (raw) & 3.9 & 93.3 & 2.4 & 0.0 \\
Soy flour (defatted) & 3.5 & 55.5 & 1.3 & 36.6 \\
Soy protein concentrate & 3.5 & 92.9 & 3.6 & 0.0 \\
Wheat flour & 4.2 & 13.8 & 1.9 & 83.7 \\
\hline
\end{tabular}

All values are given in reference to dry weight

Data from USDA (2018) and Finnigan et al. (2017)
Studies using the protein digestibility-corrected amino acid score (PDCAAS), which quantifies protein quality for human consumption on a scale from 0 to $100 \%$ (Schaafsma 2000), have shown that the Quorn ${ }^{\mathrm{TM}}$ "mycoprotein" ingredient exhibits a protein quality (PDCAAS 96-97\%; Edwards and Cummings 2010) equivalent to high-quality protein sources such as egg $(100 \%)$ and cow's milk (100\%) while also exceeding that of soy $(91 \%)$ and beef $(92 \%)$. The protein quality of biomass derived from spent brewer's yeast as quantified by PDCAAS ranges from 62 to $90 \%$ depending on how the biomass is processed (Pacheco et al. 1997; Yamada and Sgarbieri 2005). Some so-called "oleaginous" microorganisms have the ability to accumulate lipids up to $50-70 \%$ of the total biomass dry weight when they are cultivated under conditions of low nitrogen availability (Ochsenreither et al. 2016). These lipids can then be extracted from the microbial biomass as SCOs and subsequently be used as food and feed supplements. A sub-set of oleaginous microorganisms are capable of producing high proportions of beneficial polyunsaturated fatty acids (PUFAs), which include omega-3 fatty acids (Adarme-Vega et al. 2012). The main source of carbohydrates in microbial biomass derives from the cell wall fraction, which consists of cellulose, pectin, mannan and/or xylan in eukaryotic microalgae, peptidoglycan in bacteria while the cell walls of yeasts and filamentous fungi are composed of $\beta$-glucan and chitin.

Microbial biomass can supply not only protein and lipids but also several vitamins, which includes many vitamins of the B family such as biotin, folic acid, niacin, pantothenic acid, pyridoxine, riboflavin and thiamine (Ritala et al. 2017). One notable exception is vitamin B12 (cyanocobalamin), which is a corrinoid compound only produced by certain bacteria and archaea and subsequently accumulates via the food chain in phytoplankton and the tissues of animals (Watanabe and Bito 2018). Good microbial sources of vitamin B12 include the edible eukaryotic microalga Chlorella (Watanabe et al. 1997) while the predominant corrinoid compound in Spirulina biomass is pseudovitamin B12, which is inactive in human tissues (Watanabe et al. 2002). In cases where the bulk of human or animal diets were to consist of microbial biomass derived from microorganisms that do not produce vitamin B12 themselves (such as many bacteria as well as all currently known yeasts and filamentous fungi), supplementation with suitable microbial sources of vitamin B12 would be essential. Other important nutrients that can be derived from microorganisms include vitamins $\mathrm{C}$ and $\mathrm{E}$, which are produced by eukaryotic microalgae and some cyanobacteria (Ritala et al. 2017). Microalgae and cyanobacteria as well as some yeasts and non-photosynthetic bacteria can also produce valuable carotenoid pigments such as $\beta$-carotene - the metabolic precursor of vitamin A, and astaxanthin, which is the source of the orange and red hues of crustacean shells and salmon meat (Vachali et al. 2012).

In addition to satisfying nutritional requirements, microbial biomass that is used to replace conventional sources of animal feed must also be palatable to the production animal while at 
the same time maintaining animal performance (e.g. rate of weight gain, milk yield), animal welfare and final product quality (e.g. flavor, aroma, texture, color, fatty acid profile). For example, studies of Spirulina biomass used as feed in tilapia (Oreochromis niloticus) aquaculture have shown that complete replacement of conventional feeds with Spirulina biomass does not significantly affect meat color, texture or taste (Lu and Takeuchi 2002) but that feed replacement levels above $30 \%$ negatively affect growth performance and animal health (Velasquez et al. 2016). Dairy cows that were fed $200 \mathrm{~g}$ Spirulina per day in addition to their regular feed resulted in increased milk yields as well as higher levels of PUFAs in the milk (Kulpys et al. 2009). However, in the case of beef cattle, supplementation of cattle feed with biomass from the PUFArich microalga Aurantiochytrium limacinum was shown to increase meat PUFA levels but caused undesirable meat offflavors and accelerated meat discoloration (Phelps et al. 2016a, b). Biomass derived from the methanotrophic bacterium Methylococcus capsulatus has positive effects on animal performance and product quality in a range of monogastric production animals including pigs, broiler chickens, mink, fox and several species of farmed fish (reviewed by Øverland et al. 2010). For example, partially replacing soybean meal with $M$. capsulatus biomass in broiler chicken feed decreased lipid oxidation in broiler meat during frozen storage without affecting taste (Øverland et al. 2011). M. capsulatus biomass also alleviates negative effects of other feed components. Farmed Atlantic salmon (Salmo salar) that are fed soybean meal tend to develop a type of distal gut inflammation known as soybean meal-induced enteritis (Baeverfjord and Krogdahl 1996). However, if the salmon are fed a mixture of soybean meal and formulated $M$. capsulatus biomass, no such inflammation occurs (Romarheim et al. 2011).

Potential food and feed safety concerns of edible microbial biomass include allergic reactions, endogenous toxins as well as biotic and abiotic toxic contaminants introduced during the production process. There are reported cases of allergic reactions and other immune responses in humans caused by ingestion of microbial biomass in the form of food or supplements (Higson 1989; Jacobson 2003; Le et al. 2014) or inhalation of dust from dried microbial biomass by factory workers during its production (Ekenvall et al. 1983; Sikkeland et al. 2009). Some microorganisms such as filamentous fungi, cyanobacteria and eukaryotic microalgae can produce highly potent toxins (Richard 2007; Vilariño et al. 2018), which necessitates careful evaluation during the introduction of new microbial species for food and feed applications. Large-scale cultivation facilities must also be carefully monitored for the presence of potentially toxin-producing contaminants. The use of closed cultivation systems such as large fermentation tanks, although capital-intensive, not only allow for the optimization of both nutrient utilization and water use but also enable fairly efficient control of the microbial population (by preventing the introduction of contaminants). Photosynthetic microorganisms such as cyanobacteria and eukaryotic microalgae require access to light and are therefore often cultivated in open ponds. As a consequence, such open systems are more vulnerable to contamination from particulate matter, other undesirable (and potentially toxin-producing) photosynthetic microorganisms (Heussner et al. 2012) in addition to algal parasites such as viruses as well as predatory zooplankton (Wang et al. 2013). Closed cultivation systems for photosynthetic microorganisms can counter these problems but result in increased capital costs.

\section{Possible routes towards producing edible microbial biomass from $\mathrm{CO}_{2}$}

Any process directly utilizing $\mathrm{CO}_{2}$ as a substrate has the potential to be $\mathrm{C}$ neutral, provided that the $\mathrm{CO}_{2}$ substrate is not produced concurrently from fossilized $\mathrm{C}$. This makes $\mathrm{CO}_{2}$ a very attractive feedstock for the sustainable production of edible microbial biomass. As a feedstock, $\mathrm{CO}_{2}$ is essentially free and theoretically accessible from anywhere in the world with access to the atmosphere. However, with the exception of cultivating photosynthetic microorganisms, the relatively low concentration $\left(0.04 \%\right.$ per weight) of $\mathrm{CO}_{2}$ in ambient air (Le Quéré et al. 2018) means that energy and other resources must first be expended to capture and concentrate atmospheric $\mathrm{CO}_{2}$ in order to ensure an efficient conversion process. $\mathrm{CO}_{2}$ can be captured from ambient air with the help of $\mathrm{CO}_{2}$-binding materials called adsorbents (Goeppert et al. 2012). The captured $\mathrm{CO}_{2}$ is then extracted from the adsorbent, which may involve heat or moisture depending on the chemical properties of the particular adsorbent. Following $\mathrm{CO}_{2}$ extraction, the adsorbent can subsequently be regenerated for additional cycles of $\mathrm{CO}_{2}$ capture. One alternative to direct chemical capture and extraction of $\mathrm{CO}_{2}$ from ambient air is to harvest concentrated $\mathrm{CO}_{2}$ instead from industrial exhaust gas (commonly known as flue gas) from emission-intensive industries such as coal-fired power plants, cement factories or metal works. However, $\mathrm{CO}_{2}$-capture from flue gas would only temporarily offset the environmental impact of these industrial processes but do not offer a long-term path for transitioning to $\mathrm{C}$ neutral production of microbial biomass for food and feed applications. As in the previous case of microbial biomass produced from natural gas, the $\mathrm{C}$ fraction of microbial biomass produced from $\mathrm{CO}_{2}$ that in turn has been derived from fossilized $\mathrm{C}$ would simply re-enter the atmosphere following cellular respiration after ingestion.

A number of companies are currently developing technology platforms for $\mathrm{CO}_{2}$-capture and extraction from ambient air or geological sources (Table 3). $\mathrm{CO}_{2}$ captured in this manner can be used directly as a feedstock for the cultivation of either photosynthetic microorganisms (such as cyanobacteria 
Table 3 Examples of companies currently engaged in $\mathrm{CO}_{2}$ capture and conversion

\begin{tabular}{lll}
\hline Company name & $\mathrm{CO}_{2}$ source & Conversion \\
\hline Carbon Engineering & Ambient air & Yes ("drop-in fuels") \\
Carbon Recycling International & Geothermal steam emissions & Yes (methanol) \\
Climeworks & Ambient air & No \\
Global Thermostat & Ambient air & No \\
\hline
\end{tabular}

or eukaryotic microalgae; Fig. 2a) or chemoautotrophic microorganisms, such as $\mathrm{H}_{2}$-oxidizing chemoautotrophic bacteria (Fig. 2b). In the latter case, $\mathrm{H}_{2}$ gas can be produced by electrolysis of water using zero-emission energy sources such as solar, wind, hydro or nuclear. The use of $\mathrm{H}_{2}$-oxidizing chemoautotrophic bacteria for the production of edible microbial biomass from $\mathrm{CO}_{2}$ was already proposed several decades ago as a circular food production system for space travel (Foster and Litchfield 1964). The Finnish start-up Solar Foods has recently announced that they will bring a microbial food product to market by 2021 , which is based on $\mathrm{H}_{2}$-oxidizing chemoautotrophic bacteria.

Some of the companies listed in Table 3 have focused exclusively on $\mathrm{CO}_{2}$ capture and storage while others have coupled the capture and extraction process to chemical conversion of $\mathrm{CO}_{2}$ into an organic compound. These organic compounds are typically intended for use as carbon-neutral fuels (e.g. methanol; Olah 2013) or as starting materials for chemical synthesis of plastics and other organic bulk materials. However, these processes can easily be repurposed to produce organic feedstocks from $\mathrm{CO}_{2}$ for the cultivation of edible microbial biomass. For example, $\mathrm{CO}_{2}$ that has been hydrogenated into methanol through chemical catalysis (Olah 2013) can be used for the cultivation of methylotrophic bacteria and fungi (Fig. 2c). Formic acid can be synthesized electrochemically from $\mathrm{CO}_{2}$ and water, which has previously been used in an integrated electromicrobial system for labscale production of fuel-grade alcohols by methylotrophic bacteria (Li et al. 2012). Such a process can be reconfigured for the direct production of edible microbial biomass from formic acid that has been synthesized electrochemically from $\mathrm{CO}_{2}$ and water (Fig. 2d).

There are also a number of microbial biocatalytic processes that are capable of converting $\mathrm{CO}_{2}$ into simple organic compounds, which can subsequently be used as feedstocks for cultivation of a different set of microorganisms to be used as food or feed. The biocatalytic conversion of $\mathrm{CO}_{2}$ into organic feedstocks must usually occur in the absence of oxygen as the microorganisms involved tend to be highly oxygen-sensitive. One such group are acetogenic (acetic acidproducing) bacteria, which have the ability to harness the chemical energy of $\mathrm{H}_{2}$ gas to convert $\mathrm{CO}_{2}$ into acetic acid in a process called syngas fermentation (Latif et al. 2014). The resulting acetic acid can then be used to cultivate acetotrophic bacteria or fungi to be used as food or feed
(Fig. 2e). Such an integrated process has already been demonstrated in the scientific literature, where the acetogenic bacterium Moorella thermoacetica was used to convert a $\mathrm{CO}_{2} / \mathrm{H}_{2}$ mixture into acetic acid, which was then used for cultivation of the acetotrophic oleaginous yeast Yarrowia lipolytica $(\mathrm{Hu}$ et al. 2016). Although the purpose of this particular proof-ofconcept study was to produce diesel-like lipids for fuel applications, the process can be directly repurposed to produce lipids for food and feed applications. In addition, simply increasing the proportion of nitrogen to carbon in the cultivation medium favors the production of proteins over lipids in $Y$. lipolytica (Sestric et al. 2014). It has recently been shown that some acetogenic bacteria have the ability to harness electrical energy through direct physical contact with electrodes (Nevin et al. 2010). Acetic acid production by such "electrotrophic" acetogenic bacteria (Fig. 2f) circumvents the need for $\mathrm{H}_{2}$ gas. This not only increases the overall efficiency of the process but also avoids issues of $\mathrm{H}_{2}$ gas transport and storage as well as the associated explosion hazard.

Methane can also be produced from $\mathrm{CO}_{2}$ by biocatalysis using methanogenic (methane-producing) archaea. The methane can then be used as a feedstock for the cultivation of methanotrophic bacteria (Fig. $2 \mathrm{~g}, \mathrm{~h}$ ). The production of methane from $\mathrm{CO}_{2}$ and $\mathrm{H}_{2}$ by methanogenic archaea is well established and commonly referred to as hydrogenotrophic methanogenesis. This process occurs naturally during biogas production from organic waste but could also be employed for methane production from pure $\mathrm{CO}_{2} / \mathrm{H}_{2}$ mixtures (Zabranska and Pokorna 2018). As in the case of syngas fermentation described above, $\mathrm{H}_{2}$ gas could be produced through electrolysis of water using zero-emission energy sources. There have also been a number of reports in the scientific literature that describe archaea capable of electrotrophic methanogenesis (Beese-Vasbender et al. 2015; Cheng et al. 2009) where the archaea grow on electrodes and can harness electrical energy directly to produce methane. As in the case of electrotrophic acetogenesis described previously, this would also circumvent the need to produce, transport and store $\mathrm{H}_{2}$ gas for the production of methane as a feedstock.

In summary, a number of technology options already exist for the capture, extraction and conversion of atmospheric $\mathrm{CO}_{2}$ into edible microbial biomass. (The conversion routes listed in Fig. 2 should not be considered exhaustive.) It should be emphasized that there is no technological barrier preventing the immediate deployment of this technology for the production 
of food and feed. However, the impact that this technology can have on the global food production system and the environment will depend on its cost-effectiveness, at what scale it can be deployed and at what speed, which will likely hinge on financial and regulatory incentives as will be discussed below.

\section{Future possibilities, challenges and risks}

Current global food production is ultimately constrained by the rate at which atmospheric $\mathrm{CO}_{2}$ is converted into edible biomass through photosynthesis. The term net primary production (NPP) is used to describe the total amount of accumulated organic $\mathrm{C}$ fixed from $\mathrm{CO}_{2}$ through chemo- and photosynthesis within a set geographical area and time span, typically one year (Field et al. 1998). Global NPP sets a theoretical upper limit to the amount of biomass available for human appropriation through activities such as agriculture, forestry and fishing (Running 2012). However, the rate of global food production could theoretically be increased beyond the current NPP boundary through localized increases of photosynthetic activity that would boost the rate of $\mathrm{CO}_{2}$ fixation. This could be accomplished by for example expanding crop production into geographical locations with low NPP such as arid regions (e.g. through desert agriculture) or offshore marine areas (e.g. through large-scale cultivation of macroalgae; Rebours et al. 2014).

Industrial $\mathrm{CO}_{2}$-to-microbial biomass conversion as described in the previous section presents a radically different strategy to circumvent the current global NPP boundary. One obvious advantage of the seven non-photosynthetic $\mathrm{CO}_{2}$-tomicrobial biomass conversion routes described in the previous section (Fig. 2b-h) is that, unlike cultivation of land-based crops or algae, these processes are not absolutely dependent on sunlight and are therefore not confined to two-dimensional food production systems but can instead be stacked in three dimensions. The true magnitude of this property can be appreciated through a comparison of soybean yields with the production capacity of the Imperial Chemical Industries bioreactor design, which was used for continuous production of bacterial biomass from methanol during the 1980s. The now demolished cultivation tank, which was located in Billingham, UK, was $60 \mathrm{~m}$ tall and 7-11 $\mathrm{m}$ wide with an operating volume of $1500 \mathrm{~m}^{3}$ and an annual output of 50-60 kt of dry bacterial biomass (Westlake 1986). This would roughly translate to $413-496 \mathrm{t}$ of dry microbial biomass $/ \mathrm{m}^{2} /$ year, if discounting the surrounding area that would be required for downstream processing infrastructure. One hectare of land could theoretically house 82 such vessels (provided the ground beneath could withstand the weight) and would have a combined annual output of 4.1-4.9 Mt. of dry bacterial biomass. In comparison, the average US soybean yield in 2017 was $3.3 \mathrm{t}$ wet weight per hectare (FAOSTAT 2019).
Fig. 2 Possible routes for conversion of $\mathrm{CO}_{2}$ into microbial biomass. a Direct conversion of $\mathrm{CO}_{2}$ into biomass by photoautotrophic microorganisms such as cyanobacteria or eukaryotic microalgae. b Direct conversion of $\mathrm{CO}_{2}$ into biomass by $\mathrm{H}_{2}$-oxidizing chemoautotrophic bacteria. c Catalytic conversion of $\mathrm{CO}_{2}$ into methanol that is then used to cultivate methylotrophic bacteria or fungi. d Electrocatalytic conversion of $\mathrm{CO}_{2}$ into formic acid that is then used to cultivate methylotrophic bacteria or fungi. e Biocatalytic conversion of $\mathrm{CO}_{2}$ into acetic acid using bacteria capable of hydrogenotrophic acetogenesis (syngas fermentation). The resulting acetic acid is used to cultivate acetotrophic bacteria or fungi. f Biocatalytic conversion of $\mathrm{CO}_{2}$ into acetic acid by bacteria capable of electrotrophic acetogenesis. The resulting acetic acid is used to cultivate acetotrophic bacteria or fungi. $\mathbf{g}$ Biocatalytic conversion of $\mathrm{CO}_{2}$ into methane using archaea capable of hydrogenotrophic methanogenesis. The resulting methane is used to cultivate methanotrophic bacteria. $\mathbf{h}$ Biocatalytic conversion of $\mathrm{CO}_{2}$ into methane using archaea capable of electrotrophic methanogenesis. The resulting methane is used to cultivate methanotrophic bacteria

Another attractive property of non-photosynthetic $\mathrm{CO}_{2}$-tomicrobial biomass processes is that energy generation can be geographically decoupled from $\mathrm{CO}_{2}$ capture, extraction and conversion into microbial biomass. In a scenario where solar power would be used as the energy source for capture and conversion of $\mathrm{CO}_{2}$ into microbial biomass, sunlight could be harvested in arid regions with high solar irradiance where there is no competition between photovoltaic panels and agriculture. The resulting electrical energy could then be transmitted hundreds of kilometers through the electricity grid to the location where $\mathrm{CO}_{2}$ capture, extraction and conversion into microbial biomass can take place. One added advantage of using solar power rather than photosynthesis is that the efficiency of photovoltaic panels is an order of magnitude higher than of photosynthesis (Blankenship et al. 2011). However, non-photosynthetic $\mathrm{CO}_{2}$-to-microbial biomass conversion processes (Fig. $2 \mathrm{~b}-\mathrm{h}$ ) are not limited to solar energy, which theoretically allows for production of microbial biomass anywhere in the world independently of local climate conditions or land availability as long as there is access to energy, $\mathrm{CO}_{2}$ and water. These processes could also provide a novel form of energy storage capacity for intermittent energy sources such as solar or wind, where excess electricity could be used to sequester atmospheric $\mathrm{CO}_{2}$ and convert it to simple organic feedstocks (Fig. 1b) for later cultivation of edible microorganisms.

The rate at which global production of edible microbial biomass can be scaled up will depend on regulatory incentives, consumer acceptance as well as the degree of competition from conventional alternatives. The global success of Quorn $^{\mathrm{TM}}$ has demonstrated a willingness by consumers to transition to microbial food products as a vegetarian alternative to meat (Finnigan et al. 2017). Increased awareness of the possible environmental benefits of microbial food products in general (provided a sustainable feedstock is used for its production) may also increase adoption rates. A key factor that will influence adoption rates is the cost to the consumer - and 
a

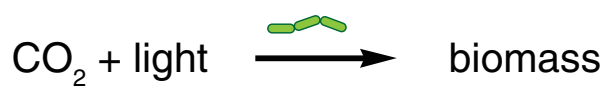

b

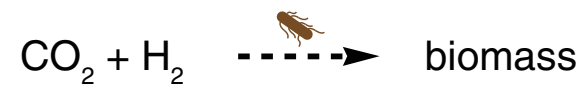

c

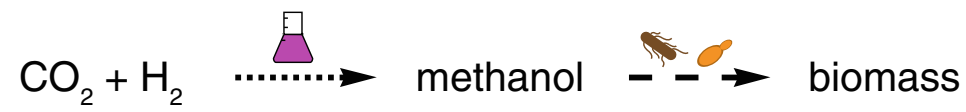

d

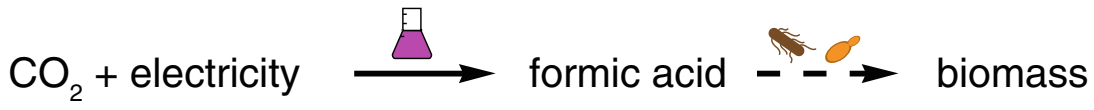

e

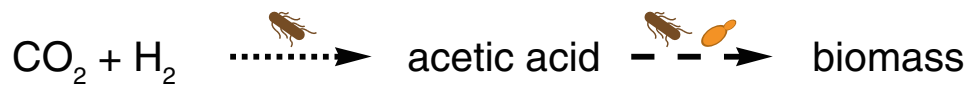

$\mathbf{f}$

$\mathrm{CO}_{2}+$ electricity $\quad \cdots \cdots \rightarrow$ acetic acid $-\rightarrow \rightarrow$ biomass

g

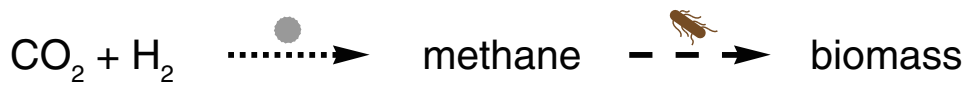

$\mathbf{h}$

$\mathrm{CO}_{2}+$ electricity

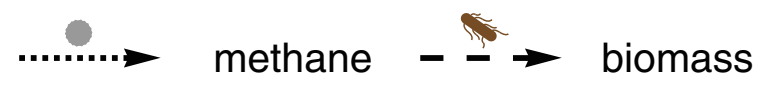

\begin{tabular}{|c|c|}
\hline ס & $\begin{array}{l}\text { cyanobacteria, } \\
\text { microalgae }\end{array}$ \\
\hline 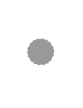 & $\begin{array}{l}\text { methanogenic } \\
\text { archaea }\end{array}$ \\
\hline$\pi$ & $\begin{array}{l}\text { non-photosynthetic } \\
\text { bacteria }\end{array}$ \\
\hline$\infty$ & $\begin{array}{l}\text { yeasts, filamentous } \\
\text { fungi }\end{array}$ \\
\hline 8 & $\begin{array}{l}\text { chemical } \\
\text { catalysis }\end{array}$ \\
\hline
\end{tabular}

it should be noted that in the case of Quorn ${ }^{\mathrm{TM}}$, these products often retail at higher prices than conventional meat (author's own observation). Another factor specific to Quorn ${ }^{\mathrm{TM}}$ products is that they require frozen storage in order to maintain the desired meat-like texture (Finnigan et al. 2017). This becomes a hurdle in developing economies where limited income and access to electricity restricts freezer ownership. In such cases, dry powder formulations will be a more feasible alternative, as demonstrated by the local use of sun-dried Spirulina as food in Central Africa (Abdulqader et al. 2000). 
From the perspective of consumer acceptance, the animal feed sector might be more accessible to microbial alternatives in the immediate future in a situation analogous to the broad adoption of genetically modified soybean for animal feed. Despite consumer aversion to genetically modified organisms, 30 non-planting countries (including the EU) still import genetically modified soybeans and $77 \%$ of the global area dedicated to soybean cultivation in 2017 consisted of genetically modified variants (ISAAA 2018). One key factor that will determine the extent to which microbial sources of feed can reduce the environmental footprint of animal foods is the inclusion threshold, i.e. what proportion of conventional feeds can be substituted for microbial biomass without incurring productivity losses, decreased product quality or negative effects on animal welfare. The feed properties of microbial biomass depend on its amino acid and fatty acid profiles as well as possible physiological or immunological responses of the production animal to other microbial cell components such as the outer cell wall or other bioactive compounds. Current microbial feed products (Table 1) consist of endogenous protein only, which may or may not contain the optimal amino acid profiles for the target animal in question (Boisen et al. 2000). However, many microorganisms can easily be genetically engineered to produce well-characterized feed proteins from non-microbial sources - or even produce entirely novel, customized proteins with superior digestibility, tailor-made amino acid profiles and reduced allergenic potential. A number of genes encoding seed storage proteins from plants have successfully been inserted into the genomes of yeast for recombinant protein production at laboratory scale (Consonni et al. 2010; Lin et al. 2004; Medina-Godoy et al. 2006). Such recombinant (and potentially customized) feed protein could allow for a higher inclusion threshold than endogenous microbial protein, potentially to a degree where it could completely replace conventional sources of protein feed. In addition, it is possible to engineer microorganisms to secrete feed or food proteins directly into the surrounding growth medium, which can then be harvested separately from the microbial biomass. This approach has been used routinely for decades in the production of recombinant peptide hormones (e.g. human insulin) as well as recombinant enzymes for industrial applications. In this manner it would be possible to avoid any potential negative effects on animal welfare or consumer health that would otherwise be caused by microbial cell components. However, it should be noted that recombinant proteins meant for food or feed applications are governed by separate regulations from proteins meant for medical or industrial applications (EFSA 2011).

Microbial production of recombinant plant or animal proteins for human consumption may prove more acceptable to consumers than microbial biomass itself. The company Perfect Day Inc. (San Francisco, CA, USA) is developing animal-free dairy products through the production of animal milk proteins in yeast cultivated on a sugar feedstock (Pandya et al. 2016), although this process could also employ $\mathrm{CO}_{2}$-derived feedstocks such as methanol or acetic acid. Impossible Foods Inc. (Redwood City, CA) has developed a strain of transgenic yeast containing a gene from soy for production of the protein leghemoglobin (Fraser et al. 2018; Jin et al. 2018), which is used as an ingredient in plant protein-based meat substitutes in order to mimic the flavors, aroma and cooking properties of real meat. The recombinant leghemoglobin produced by Impossible Foods Inc. has been designated "generally recognized as safe" (GRAS) by the US Food and Drug Administration (FDA 2018) and plant-based meat-imitation products containing recombinant leghemoglobin are already commercially available for human consumption under the Impossible ${ }^{\mathrm{TM}}$ brand. Leghemoglobin is a heme-containing oxygen-transport protein analogous to animal hemoglobin and myoglobin. The muscle protein myoglobin is responsible for producing many of the distinct flavors when animal muscle is cooked, which can be mimicked by recombinant soy leghemoglobin. The function of leghemoglobin in nature is to manage oxygen availability in specialized root nodules of soy and other legumes, where oxygen-sensitive symbiotic bacteria convert atmospheric nitrogen gas $\left(\mathrm{N}_{2}\right)$ into ammonia. The plant can then assimilate the ammonia for the production of nitrogen-requiring biomolecules such as proteins and nucleic acids. Although recombinant soy leghemoglobin is currently used in food as a flavoring agent, in the future it could also be used as a nutritional supplement in food to counteract chronic iron deficiency, especially in low- and middleincome countries (Pasricha et al. 2013), since heme-bound iron in the diet is better absorbed than free iron.

In theory, microbial sources of food and feed hold great promise for achieving a future food production system that is both more sustainable and more resilient. A recently published model simulation showed that it would be feasible to replace $10-19 \%$ of conventional crop-based protein feed with microbial biomass by 2050 , with significant reductions in global cropland area, nitrogen leakage and agricultural GHG emissions (Pikaar et al. 2018). Should global agricultural output suddenly decline due to a sudden cataclysmic event (e.g. a major war, global pandemic, extreme weather event or asteroid impact), globally distributed $\mathrm{CO}_{2}$ capture and extraction facilities coupled to production of edible microbial biomass could act as a buffer against mass starvation and the social unrest that would likely result from it. Nevertheless, careful environmental assessments must be carried out to identify potential trade-offs and unintended consequences of large-scale production of microbial sources of food and feed. Following the industrial revolution of the early nineteenth century, the British economist William Stanley Jevons formulated what was later named "Jevons' paradox" (Sorrell 2009), which stipulates that any increase in 
efficiency of resource utilization results in a counterintuitive increase in overall resource consumption rather than a decrease. In the case of agricultural production, Jevons' paradox implies that an increase in yield per unit surface area would not translate into an equivalent reduction in land area dedicated to agriculture (a phenomenon known as "landsparing"), which has subsequently been demonstrated to be the case (Rudel et al. 2009). It would therefore seem likely that a large-scale transition to non-photosynthetic means of food and feed production from microorganisms would not automatically translate into actual land-sparing without additional regulatory intervention. Likewise the question remains whether scaling up industrial $\mathrm{CO}_{2}$ capture for production of food, feed and other microbial products would disincentivize reductions in anthropogenic $\mathrm{CO}_{2}$ emissions and delay or even halt the phasing out of fossil fuels. Food waste is a significant reason for resource use inefficiency in the current global food production system with approximately one quarter of food being wasted from field to consumer (Kummu et al. 2012). It would be prudent to ask whether there is a risk that community efforts and government policies to reduce food waste will slow or cease altogether in a future scenario where the food production system is no longer absolutely dependent on photosynthetic $\mathrm{CO}_{2}$-fixation.

Just over a century ago the invention of industrial ammonia synthesis from atmospheric $\mathrm{N}_{2}$ gas by the German chemist Fritz Haber led to a revolution in food production as humanity was no longer dependent on biological nitrogen fixation (Erisman et al. 2008). However, higher agricultural yields came at the price of increased fertilizer leakage and run-off leading to eutrophication. In addition, microorganisms in the environment can convert excess nitrogen fertilizer into the highly potent GHG nitrous oxide $\left(\mathrm{N}_{2} \mathrm{O}\right)$. Although it is possible to synthesize ammonia from atmospheric $\mathrm{N}_{2}$ gas using zero-emission energy sources (Service 2018), essentially all industrial ammonia synthesis today uses fossil fuels - predominantly natural gas, which results in substantial $\mathrm{CO}_{2}$ emissions. The reason is simply that the use of fossil fuels is cheaper and more energy efficient than most renewable alternatives (Tunå et al. 2014) and no significant regulatory pressure currently exists that would favor fossil-free ammonia synthesis. Thus the example of industrial nitrogen fixation clearly illustrates the point that the mere existence of a sustainable technology option will not guarantee its deployment in the absence of financial or regulatory incentives. Large-scale $\mathrm{CO}_{2}$-fixation independent of photosynthesis would seem like an obvious next technology leap in global food production. Whether this scenario will come to pass (and if so, whether it will fulfill its potential for environmental sustainability and food security) will depend less on the technology itself and more on the scale at which it will be deployed and what choices are made on how it will be implemented.
Acknowledgements I would like to credit Prof James Liao (University of California Los Angeles, USA), whose presentation on electromicrobial processes ( $\mathrm{Li}$ et al. 2012) at a 2012 research conference in Biarritz, France, was the original inspiration for writing this review article. Thanks also to Dr. Ievgeniia Tiukova (Chalmers University of Technology, Sweden) for many fruitful discussions on the topic of microbial food and feed.

\section{Compliance with ethical standards}

Conflict of interest The author declares no conflict of interest.

Open Access This article is distributed under the terms of the Creative Commons Attribution 4.0 International License (http:// creativecommons.org/licenses/by/4.0/), which permits unrestricted use, distribution, and reproduction in any medium, provided you give appropriate credit to the original author(s) and the source, provide a link to the Creative Commons license, and indicate if changes were made.

\section{References}

Abdulqader, G., Barsanti, L., \& Tredici, M. (2000). Harvest of Arthrospira platensis from Lake Kossorom (Chad) and its household usage among the Kanembu. Journal of Applied Phycology, 12(3-5), 493-498.

Adarme-Vega, T. C., Lim, D. K., Timmins, M., Vernen, F., Li, Y., \& Schenk, P. M. (2012). Microalgal biofactories: a promising approach towards sustainable omega- 3 fatty acid production. Microbial Cell Factories, 11, 96.

Baeverfjord, G., \& Krogdahl, A. (1996). Development and regression of soybean meal induced enteritis in Atlantic salmon, Salmo salar L., distal intestine: A comparison with the intestines of fasted fish. Journal of Fish Diseases, 19(5), 375-387.

Beese-Vasbender, P. F., Grote, J. P., Garrelfs, J., Stratmann, M., \& Mayrhofer, K. J. (2015). Selective microbial electrosynthesis of methane by a pure culture of a marine lithoautotrophic archaeon. Bioelectrochemistry, 102, 50-55.

Berg, I. A. (2011). Ecological aspects of the distribution of different autotrophic $\mathrm{CO}_{2}$ fixation pathways. Applied and Environmental Microbiology, 77(6), 1925-1936.

Blankenship, R. E., Tiede, D. M., Barber, J., Brudvig, G. W., Fleming, G., Ghirardi, M., Gunner, M. R., Junge, W., Kramer, D. M., Melis, A., Moore, T. A., Moser, C. C., Nocera, D. G., Nozik, A. J., Ort, D. R., Parson, W. W., Prince, R. C., \& Sayre, R. T. (2011). Comparing photosynthetic and photovoltaic efficiencies and recognizing the potential for improvement. Science, 332(6031), 805-809.

Boisen, S., Hvelplund, T., \& Weisbjerg, M. R. (2000). Ideal amino acid profiles as a basis for feed protein evaluation. Livestock Production Science, 64(2-3), 239-251.

Cassidy, E. S., West, P. C., Gerber, J. S., \& Foley, J. A. (2013). Redefining agricultural yields: from tonnes to people nourished per hectare. Environmental Research Letters, 8(3), 034015.

Cheng, S., Xing, D., Call, D. F., \& Logan, B. E. (2009). Direct biological conversion of electrical current into methane by electromethanogenesis. Environmental Science \& Technology, 43(10), 3953-3958.

Ciferri, O. (1983). Spirulina, the edible microorganism. Microbiology Reviews, 47(4), 551-578.

Consonni, A., Lovati, M. R., Manzoni, C., Pizzagalli, A., Morazzoni, P., \& Duranti, M. (2010). Cloning, yeast expression, purification and biological activity of a truncated form of the soybean $7 \mathrm{~S}$ globulin 
alpha' subunit involved in Hep G2 cell cholesterol homeostasis. Journal of Nutritional Biochemistry, 21(9), 887-891.

Cooney, C. L., Rha, C., \& Tannenbaum, R. (1980). Single-cell protein: engineering, economics, and utilization in foods. Advances in Food Research, 26, 1-52.

Despommier, D. (2009). The rise of vertical farms. Scientific American, 301(5), 80-87.

Deutsch, C. A., Tewksbury, J. J., Tigchelaar, M., Battisti, D. S., Merrill, S. C., Huey, R. B., \& Naylor, R. L. (2018). Increase in crop losses to insect pests in a warming climate. Science, 361(6405), 916-919.

Diaz, R. J., \& Rosenberg, R. (2008). Spreading dead zones and consequences for marine ecosystems. Science, 321(5891), 926-929.

Edozien, J. C., Udo, U. U., Young, V. R., \& Scrimshaw, N. S. (1970). Effects of high levels of yeast feeding on uric acid metabolism of young man. Nature, 228(5267), 180.

Edwards, D. G. \& Cummings, J. H. (2010). The protein quality of mycoprotein. Proceedings of the Nutrition Society, 69(OCE4), E331.

EFSA. (2011). Guidance on the risk assessment of genetically modified microorganisms and their products intended for food and feed use. EFSA Journal, 9(6), 2193

Ekenvall, L., Dölling, B., Göthe, C. J., Ebbinghaus, L., von Stedingk, L. V., \& Wasserman, J. (1983). Single cell protein as an occupational hazard. British Journal of Industrial Medicine, 40(2), 212-215.

Erisman, J. W., Sutton, M. A., Galloway, J., Klimont, Z., \& Winiwarter, W. (2008). How a century of ammonia synthesis changed the world. Nature Geoscience, 1, 636-639.

FAOSTAT. (2019). The food and agriculture organization corporate statistical database. Food and Agriculture Organization of the United Nations. http://www.fao.org/faostat/. Accessed 19 Feb 2019.

FDA. (2018). Response to GRAS notice no. GRN 000737.

Field, C. B., Behrenfeld, M. J., Randerson, J. T., \& Falkowski, P. (1998). Primary production of the biosphere: integrating terrestrial and oceanic components. Science, 281(5374), 237-240.

Finnigan, T., Needham, L., \& Abbott, C. (2017). Mycoprotein: a healthy new protein with a low environmental impact. In S. R. Nadathur, J. P. D. Wanasundara, \& L. Scanlin (Eds.), Sustainable protein sources (pp. 305-325). Cambridge: Academic Press.

Foley, J. A., Ramankutty, N., Brauman, K. A., Cassidy, E. S., Gerber, J. S., Johnston, M., Mueller, N. D., O'Connell, C., Ray, D. K., West, P. C., Balzer, C., Bennett, E. M., Carpenter, S. R., Hill, J., Monfreda, C., Polasky, S., Rockström, J., Sheehan, J., Siebert, S., Tilman, D., \& Zaks, D. P. M. (2011). Solutions for a cultivated planet. Nature, 478(7369), 337-342.

Foster, J., \& Litchfield, J. (1964). A continuous culture apparatus for the microbial utilization of hydrogen produced by electrolysis of water in closed-cycle space systems. Biotechnology and Bioengineering, 6(4), 441-456.

Fraser, R. Z., Shitut, M., Agrawal, P., Mendes, O., \& Klapholz, S. (2018). Safety evaluation of soy leghemoglobin protein preparation derived from Pichia pastoris, intended for use as a flavor catalyst in plantbased meat. International Journal of Toxicology, 37(3), 241-262.

Gerbens-Leenes, P. W., Nonhebel, S., \& Krol, M. S. (2010). Food consumption patterns and economic growth. Increasing affluence and the use of natural resources. Appetite, 55(3), 597-608.

Gerland, P., Raftery, A. E., Sevčíková, H., Li, N., Gu, D., Spoorenberg, T., et al. (2014). World population stabilization unlikely this century. Science, 346(6206), 234-237.

Goeppert, A., Czaun, M., Prakash, G. K. S., \& Olah, G. A. (2012). Air as the renewable carbon source of the future: an overview of $\mathrm{CO}_{2}$ capture from the atmosphere. Energy and Environmental Science, 5(7), 7833-7853.

Grassini, P., Eskridge, K. M., \& Cassman, K. G. (2013). Distinguishing between yield advances and yield plateaus in historical crop production trends. Nature Communications, 4, 2918
Hamdan, I., \& Senez, J. (1992). The economic viability of single cell protein (SCP) production in the twenty-first century. In E. DaSilva, C. Ratledge, \& A. Sasson (Eds.), Biotechnology: Economic and social aspects: Issues for developing countries (pp. 142-164). Cambridge: Cambridge University Press.

Happer, C., \& Wellesley, L. (2019). Meat consumption, behaviour and the media environment: a focus group analysis across four countries. Food Security, 11, 123-139. https://doi.org/10.1007/ s12571-018-0877-1.

Harvey, M., \& Pilgrim, S. (2011). The new competition for land: food, energy, and climate change. Food Policy, 36(supplement 1), S40 S51.

Heussner, A. H., Mazija, L., Fastner, J., \& Dietrich, D. R. (2012). Toxin content and cytotoxicity of algal dietary supplements. Toxicology and Applied Pharmacology, 265(2), 263-271.

Higson, N. (1989). An allergy to marmite? British Medical Journal, 298, 190.

Hoekstra, A. Y., \& Mekonnen, M. M. (2012). The water footprint of humanity. Proceedings of the National Academy of Sciences USA, 109(9), 3232-3237.

Horton, P. (2017). We need radical change in how we produce and consume food. Food Security, 9(6), 1323-1327.

Hu, P., Chakraborty, S., Kumar, A., Woolston, B., Liu, H., Emerson, D., \& Stephanopoulos, G. (2016). Integrated bioprocess for conversion of gaseous substrates to liquids. Proceedings of the National Academy of Sciences USA, 113(14), 3773-3778.

Hug, L. A., Baker, B. J., Anantharaman, K., Brown, C. T., Probst, A. J., Castelle, C. J., Butterfield, C. N., Hernsdorf, A. W., Amano, Y., Ise, K., Suzuki, Y., Dudek, N., Relman, D. A., Finstad, K. M., Amundson, R., Thomas, B. C., \& Banfield, J. F. (2016). A new view of the tree of life. Nature Microbiology, 1, 16048.

ISAAA. (2018). Brief 53: Global status of commercialized biotech/GM crops: 2017. International Service for the Acquisition of Agribiotech Applications.

Jacobson, M. F. (2003). Adverse reactions linked to Quorn-brand foods. Allergy, 58(5), 455-456.

Jarrell, K. F., Walters, A. D., Bochiwal, C., Borgia, J. M., Dickinson, T., \& Chong, J. P. (2011). Major players on the microbial stage: why archaea are important. Microbiology, 157(4), 919-936.

Jin, Y., He, X., Andoh-Kumi, K., Fraser, R. Z., Lu, M., \& Goodman, R. E. (2018). Evaluating potential risks of food allergy and toxicity of soy leghemoglobin expressed in Pichia pastoris. Molecular Nutrition \& Food Research, 62(1), 1700297.

Jones, N. (2010). A taste of things to come? Nature, 468(7325), 752-753.

Khalid, A., Arshad, M., Anjum, M., Mahmood, T., \& Dawson, L. (2011). The anaerobic digestion of solid organic waste. Waste Management, 31, 1737-1744.

Kulpys, J., Paulauskas, E., Pilipavicius, V., \& Stankevicius, R. (2009). Influence of cyanobacteria Arthrospira (Spirulina) platensis biomass additives towards the body condition of lactation cows and biochemical milk indexes. Agronomy Research, 7(2), 823-835.

Kummu, M., de Moel, H., Porkka, M., Siebert, S., Varis, O., \& Ward, P. J. (2012). Lost food, wasted resources: Global food supply chain losses and their impacts on freshwater, cropland, and fertiliser use. Science of the Total Environment, 438, 477-489.

Latif, H., Zeidan, A. A., Nielsen, A. T., \& Zengler, K. (2014). Trash to treasure: production of biofuels and commodity chemicals via syngas fermenting microorganisms. Current Opinion in Biotechnology, 27, 79-87.

Le Quéré, C., Andrew, R. M., Friedlingstein, P., Sitch, S., Pongratz, J., Manning, A. C., et al. (2018). Global carbon budget 2017. Earth System Science Data, 10, 405-448.

Le, T. M., Knulst, A. C., \& Röckmann, H. (2014). Anaphylaxis to Spirulina confirmed by skin prick test with ingredients of Spirulina tablets. Food and Chemical Toxicology, 74, 309-310. 
Lesk, C., Rowhani, P., \& Ramankutty, N. (2016). Influence of extreme weather disasters on global crop production. Nature, 529(7584), 84-87.

Li, H., Opgenorth, P. H., Wernick, D. G., Rogers, S., Wu, T. Y., Higashide, W., Malati, P., Huo, Y. X., Cho, K. M., \& Liao, J. C. (2012). Integrated electromicrobial conversion of $\mathrm{CO}_{2}$ to higher alcohols. Science, 335(6076), 1596.

Lin, J., Fido, R., Shewry, P., Archer, D. B., \& Alcocer, M. J. (2004). The expression and processing of two recombinant $2 \mathrm{~S}$ albumins from soybean (Glycine max) in the yeast Pichia pastoris. Biochimica et Biophysica Acta, 1698(2), 203-212.

Lu, J., \& Takeuchi, T. (2002). Taste of Tilapia Oreochromis niloticus fed solely on raw Spirulina. Fisheries Science, 68(supplement 1), 987-988.

Matassa, S., Boon, N., Pikaar, I., \& Verstraete, W. (2016). Microbial protein: future sustainable food supply route with low environmental footprint. Microbial Biotechnology, 9(5), 568-575.

McKenzie, F. C., \& Williams, J. (2015). Sustainable food production: constraints, challenges and choices by 2050. Food Security, 7(2), 221-233.

Medina-Godoy, S., Valdez-Ortiz, A., Valverde, M. E., \& Paredes-López, O. (2006). Endoplasmic reticulum-retention C-terminal sequence enhances production of an 11S seed globulin from Amaranthus hypochondriacus in Pichia pastoris. Biotechnology Journal, 1(10), 1085-1092.

Montgomery, D. R. (2007). Soil erosion and agricultural sustainability. Proceedings of the National Academy of Sciences USA, 104(33), 13268-13272.

Nevin, K. P., Woodard, T. L., Franks, A. E., Summers, Z. M., \& Lovley, D. R. (2010). Microbial electrosynthesis: feeding microbes electricity to convert carbon dioxide and water to multicarbon extracellular organic compounds. MBio, $1(2)$. https://doi.org/10.1128/mBio. 00103-10.

Newbold, T., Hudson, L. N., Hill, S. L., Contu, S., Lysenko, I., Senior, R. A., et al. (2015). Global effects of land use on local terrestrial biodiversity. Nature, 520(7545), 45-50.

Ochsenreither, K., Glück, C., Stressler, T., Fischer, L., \& Syldatk, C. (2016). Production strategies and applications of microbial single cell oils. Frontiers in Microbiology, 7, 1539.

Olah, G. A. (2013). Towards oil independence through renewable methanol chemistry. Angewandte Chemie International Edition, 52(1), 104-107.

Onyutha, C. (2018). African crop production trends are insufficient to guarantee food security in the sub-Saharan region by 2050 owing to persistent poverty. Food Security, 10(5), 1203-1219.

Øverland, M., Tauson, A. H., Shearer, K., \& Skrede, A. (2010). Evaluation of methane-utilising bacteria products as feed ingredients for monogastric animals. Archives of Animal Nutrition, 64(3), 171-189.

Øverland, M., Borge, G. I., Vogt, G., Schøyen, H. F., \& Skrede, A. (2011). Oxidative stability and sensory quality of meat from broiler chickens fed a bacterial meal produced on natural gas. Poultry Science, 90(1), 201-210.

Pacheco, M. T., Caballero-Córdoba, G. M., \& Sgarbieri, V. C. (1997). Composition and nutritive value of yeast biomass and yeast protein concentrates. Journal of Nutritional Science and Vitaminology, 43(6), 601-612.

Pandya, R., Gandhi, P., Ji, S., Beauchamp, D., \& Hom, L. (2016). Compositions comprising a casein and methods of producing the same. World wide patent WO 16029193.

Pasricha, S. R., Drakesmith, H., Black, J., Hipgrave, D., \& Biggs, B. A. (2013). Control of iron deficiency anemia in low- and middleincome countries. Blood, 121(14), 2607-2617.

Phelps, K. J., Drouillard, J. S., O'Quinn, T. G., Burnett, D. D., Blackmon, T. L., Axman, J. E., Van Bibber-Krueger, C. L., \& Gonzalez, J. M. (2016a). Feeding microalgae meal (All-G Rich; CCAP 4087/2) to beef heifers. I: effects on longissimus lumborum steak color and palatibility. Journal of Animal Science, 94(9), 4016-4029.

Phelps, K. J., Drouillard, J. S., O'Quinn, T. G., Burnett, D. D., Blackmon, T. L., Axman, J. E., Van Bibber-Krueger, C. L., \& Gonzalez, J. M. (2016b). Feeding microalgae meal (All-G Rich; CCAP 4067/2) to beef heifers. II: Effects on ground beef color and palatability. Journal of Animal Science, 94(9), 4030-4039.

Pikaar, I., Matassa, S., Bodirsky, B. L., Weindl, I., Humpenöder, F., Rabaey, K., Boon, N., Bruschi, M., Yuan, Z., van Zanten, H., Herrero, M., Verstraete, W., \& Popp, A. (2018). Decoupling livestock from land use through industrial feed production pathways. Environmental Science and Technology, 52(13), 7351-7359.

Ray, D. K., Mueller, N. D., West, P. C., \& Foley, J. A. (2013). Yield trends are insufficient to double global crop production by 2050. PLoS One, 8(6), e66428.

Rebours, C., Marinho-Soriano, E., Zertuche-González, J. A., Hayashi, L., Vásquez, J. A., Kradolfer, P., Soriano, G., Ugarte, R., Abreu, M. H., Bay-Larsen, I., Hovelsrud, G., Rødven, R., \& Robledo, D. (2014). Seaweeds: an opportunity for wealth and sustainable livelihood for coastal communities. Journal of Applied Phycology, 26(5), 1939-1951.

Richard, J. L. (2007). Some major mycotoxins and their mycotoxicoses an overview. International Journal of Food Microbiology, 119(1-2), $3-10$.

Ritala, A., Häkkinen, S. T., Toivari, M., \& Wiebe, M. G. (2017). Single cell protein - state-of-the-art, industrial landscape and patents 20012016. Frontiers in Microbiology, 8, 2009.

Romarheim, O. H., Øverland, M., Mydland, L. T., Skrede, A., \& Landsverk, T. (2011). Bacteria grown on natural gas prevent soybean meal-induced enteritis in Atlantic salmon. The Journal of Nutrition, 141(1), 124-130.

Rudel, T. K., Schneider, L., Uriarte, M., Turner, B. L., DeFries, R., Lawrence, D., Geoghegan, J., Hecht, S., Ickowitz, A., Lambin, E. F., Birkenholtz, T., Baptista, S., \& Grau, R. (2009). Agricultural intensification and changes in cultivated areas, 1970-2005. Proceedings of the National Academy of Sciences USA, 106(49), 20675-20680.

Running, S. W. (2012). A measurable planetary boundary for the biosphere. Science, 337(6101), 1458-1459.

Schaafsma, G. (2000). The protein digestibility-corrected amino acid score. The Journal of Nutrition, 130(7), 1865S-1867S.

Service, R. F. (2018). Liquid sunshine. Science, 361(6398), 120-123.

Sestric, R., Munch, G., Cicek, N., Sparling, R., \& Levin, D. B. (2014). Growth and neutral lipid synthesis by Yarrowia lipolytica on various carbon substrates under nutrient-sufficient and nutrient-limited conditions. Bioresource Technology, 164, 41-46.

Sikkeland, L. I., Eduard, W., Stangeland, A. M., Thorgersen, E. B., Haug, T., Aukrust, P., Halvorsen, B., Mollnes, T. E., \& Kongerud, J. (2009). Occupational exposure to bacterial single cell protein induces inflammation in lung and blood. Inhalation Toxicology, 21(8), 674-681.

Singh, S. V., Ming, Z., Fennell, P. S., Shah, N., \& Anthony, E. J. (2017). Progress in biofuel production from gasification. Progress in Energy and Combustion Science, 61, 189-248.

Sorrell, S. (2009). Jevons' paradox revisited: The evidence for backfire from improved energy efficiency. Energy Policy, 37, 1456-1469.

Springmann, M., Clark, M., Mason-D'Croz, D., Wiebe, K., Bodirsky, B. L., Lassaletta, L., et al. (2018). Options for keeping the food system within environmental limits. Nature, 562(7728), 519-525.

Syngai, G. G., Gopi, R., Bharali, R., Dey, S., Lakshmanan, G. M., \& Ahmed, G. (2016). Probiotics - the versatile functional food ingredients. Journal of Food Science and Technology, 53(2), 921-933.

Tunå, P., Hulteberg, C., \& Ahlgren, S. (2014). Technoeconomic assessment of nonfossil ammonia production. Environmental Progress \& Sustainable Energy, 33(4), 1290-1297. 
Ugalde, U. O., \& Castrillo, J. I. (2002). Single cell proteins from fungi and yeasts. Applied Mycology and Biotechnology, 2, 123-149.

Unilever. (2019). Marmite. Unilever. https://www.unilever.co.uk/brands/ food-and-drink/marmite.html. Accessed 19 Feb 2019.

USDA. (2018). USDA national nutrient database for standard reference legacy release, April 2018. United States Department of Agriculture. https://ndb.nal.usda.gov/ndb/. Accessed 31 Jan 2019.

Vachali, P., Bhosale, P., \& Bernstein, P. S. (2012). Microbial carotenoids. Methods in Molecular Biology, 898, 41-59.

van Huis, A. (2013). Potential of insects as food and feed in assuring food security. Annual Review of Entomology, 58, 563-583.

Velasquez, S. F., Chan, M. A., Abisado, R. G., Traifalgar, R. F. M., Tayamen, M. M., Maliwat, G. C. F., \& Ragaza, J. A. (2016). Dietary Spirulina (Arthrospira platensis) replacement enhances performance of juvenile Nile tilapia (Oreochromis niloticus). Journal of Applied Phycology, 28(2), 1023-1030.

Vermeulen, S. J., Campbell, B. M., \& Ingram, J. S. I. (2012). Climate change and food systems. Annual Review of Environment and Resources, 37, 195-222.

Vilariño, N., Louzao, M. C., Abal, P., Cagide, E., Carrera, C., Vieytes, M. R., \& Botana, L. M. (2018). Human poisoning from marine toxins: unknowns for optimal consumer protection. Toxins, 10(8). https:// doi.org/10.3390/toxins10080324.

Wang, H., Zhang, W., Chen, L., Wang, J., \& Liu, T. (2013). The contamination and control of biological pollutants in mass cultivation of microalgae. Bioresource Technology, 128, 745-750.

Watanabe, F., \& Bito, T. (2018). Vitamin B12 sources and microbial interaction. Experimental Biology and Medicine, 243(2), 148-158.

Watanabe, F., Abe, K., Takenaka, S., Tamura, Y., Maruyama, I., \& Nakano, Y. (1997). Occurrence of cobalamin coenzymes in the photosynthetic green alga, Chlorella vulgaris. Bioscience, Biotechnology, and Biochemistry, 61(5), 896-897.

Watanabe, F., Takenaka, S., Kittaka-Katsura, H., Ebara, S., \& Miyamoto, E. (2002). Characterization and bioavailability of vitamin B12compounds from edible algae. Journal of Nutritional Science and Vitaminology, 48(5), 325-331.

Westlake, R. (1986). Large-scale continuous production of single cell protein. Chemie Ingenieur Technik, 58(12), 934-937.

Yamada, E. A., \& Sgarbieri, V. C. (2005). Yeast (Saccharomyces cerevisiae) protein concentrate: preparation, chemical composition, and nutritional and functional properties. Journal of Agricultural and Food Chemistry, 53(10), 3931-3936.
Zabranska, J., \& Pokorna, D. (2018). Bioconversion of carbon dioxide to methane using hydrogen and hydrogenotrophic methanogens. Biotechnology Advances, 36(3), 707-720.

Zhao, C., Liu, B., Piao, S., Wang, X., Lobell, D. B., Huang, Y., Huang, M., Yao, Y., Bassu, S., Ciais, P., Durand, J. L., Elliott, J., Ewert, F., Janssens, I. A., Li, T., Lin, E., Liu, Q., Martre, P., Müller, C., Peng, S., Peñuelas, J., Ruane, A. C., Wallach, D., Wang, T., Wu, D., Liu, Z., Zhu, Y., Zhu, Z., \& Asseng, S. (2017). Temperature increase reduces global yields of major crops in four independent estimates. Proceedings of the National Academy of Sciences USA, 114(35), 9326-9331.

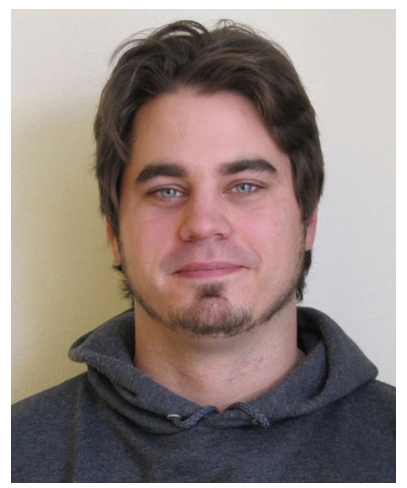

Tomas Linder received his $\mathrm{BSc}$ in molecular biology in 2000 from the University of Newcastle upon Tyne, UK. He first became interested in the biology of microorganisms during his $\mathrm{PhD}$ studies at the Karolinska Institute in Sweden, which focused on molecular mechanisms of gene regulation in yeasts. After receiving his $\mathrm{PhD}$ in 2007, he spent 2 years as a postdoctoral researcher at the University of California San Francisco in the United States. This project focused on using high-throughput genetic analysis in the common baker's yeast Saccharomyces cerevisiae to investigate carbon assimilation pathways. In 2010 he moved to the Swedish University of Agricultural Sciences in Uppsala to continue his research into yeast metabolism. His current research interests include characterization of yeast metabolic pathways involved in the degradation of anthropogenic chemicals in the environment as well as the development of specialized yeast strains for aquaculture feed applications. 